\title{
Genetic diversity of populations of the rare species Cypripedium calceolus L. in Belarus
}

\section{Natalia Samokhvalova}

Central Botanical Garden of the National Academy of Sciences of Belarus, Surganov street $2 \mathrm{~V}$, 220012, Minsk, Republic of Belarus

E-mail: samakhvalava@cbg.org.by

\begin{abstract}
Studying the level and structure of the genetic diversity of rare species is important for creating an effective strategy for their conservation. Using iPBS markers in our study, it was found that $C$. calceolus genotypes have a rather low level of genetic diversity. Genetic differentiation was found mainly within coenopopulations, which may be caused by the phenomenon of cross-pollination. The genetic distance between coenopopulations corresponded to their geographic location.
\end{abstract}

Keywords: iPBS, genetic diversity

\section{Introduction}

Loss of habitat that can be caused by human activities is a serious threat to the viability of plant populations, which can lead to their decline and extinction (Minasiewicz et al., 2018).

Studying the level and structure of the genetic diversity of rare species is important for creating an effective strategy for their conservation. Genetic diversity is essential for the development of populations, and its loss is often associated with inbred depression, which increases the risk of population extinction (Frankham, 2012). In addition to inbreeding, factors other than inbreeding can affect genetic diversity and population structure. These include the mating system, methods of pollination and seed distribution, life cycle, habitat specifics, landscape, and/or climate change (John et al., 2019).

The selection of specific populations for conservation is usually based on their contribution to the overall genetic diversity of the species. For this reason, it is important to know the degree to which populations differ from each other and the level of genetic diversity within populations. High intrapopulation genetic diversity is an important criterion when choosing priority populations for species 
conservation. In addition to contributing to overall genetic diversity, sufficiently high intrapopulation genetic variability is critical for the long-term survival of a population and the ability to adapt to environmental changes (Guo et al., 2019). The investigation aims to study the level and structure of the genetic diversity of the coenopopulations of Cypripedium calceolus L. growing in Belarus using molecular iPBS markers.

\section{Materials and methods}

Ladies' slipper (Cypripedium calceolus L.) is a perennial short-rhizome plant with a straight leafy stem $15-50 \mathrm{~cm}$ high. The flowers are large, $6-8 \mathrm{~cm}$ in diameter, with a plump lip, similar to a shoe. $C$. calceolus reproduces by vegetative and seed methods, like most members of the orchid family, the mycosymbiont. The area covers most of Europe (except for the south). A relict in origin species of the Euro-Siberian subtaiga, located on the territory of Belarus in isolated places of the European fragment of the range. It has III national protection category (according to the IUCN scale: VU - vulnerable species). Included in Appendix II to the CITES Convention, included in Appendix I to the Berne Convention, and Appendix II to the European Union Habitats Directive. Protected in Ukraine, the Russian Federation (including the Smolensk region), Poland, Lithuania, and Latvia (Kachanovsky, 2015).

In 2020, field studies were carried out in the southern part of the Republic of Belarus to determine the vitality status of $C$. calceolus coenopopulations. Three habitats were examined in the "Divin - Velikiy Les" reserve (DV1, DV2, DV3), located in the island calciphyte localities. These places of growth of the coenopopulation were described in detail in the monograph by N. V. Mikhalchuk (Mikhalchuk, 1997). The fourth habitat is also located in an island location at a sufficient distance from "Divin", on the territory of the "Vygonoshchanskoye" (VG) reserve (Figure 1). The islands of the "Divin" nature reserve are distinguished by great floristic diversity and greater anthropogenic disturbance. The coenopopulation of the "Vygonoshchanskoe" reserve is characterized by a close to the natural character of vegetation, the closeness of the tree layer, and high soil moisture. All four coenopopulations are located at the ecological optimum.

To determine the level of genetic diversity of four coenopopulations of C. calceolus, we used molecular markers iPBS (Kalendar et al., 2010). The iPBS amplification method relies on the almost universal presence of a complementary tRNA sequence as a reverse transcriptase primer binding site (PBS) in LTR retrotransposons. This method is excellent for assessing population diversity due to its high reliability and reproducibility of results, the ability to detect a large number of polymorphic fragments, and relatively low cost (Kalendar et al., 2010). In addition, since iPBS does 
not require any prior knowledge of target sequences, this marker is especially suitable for rare orchids, for which molecular genetic studies have been scarce.

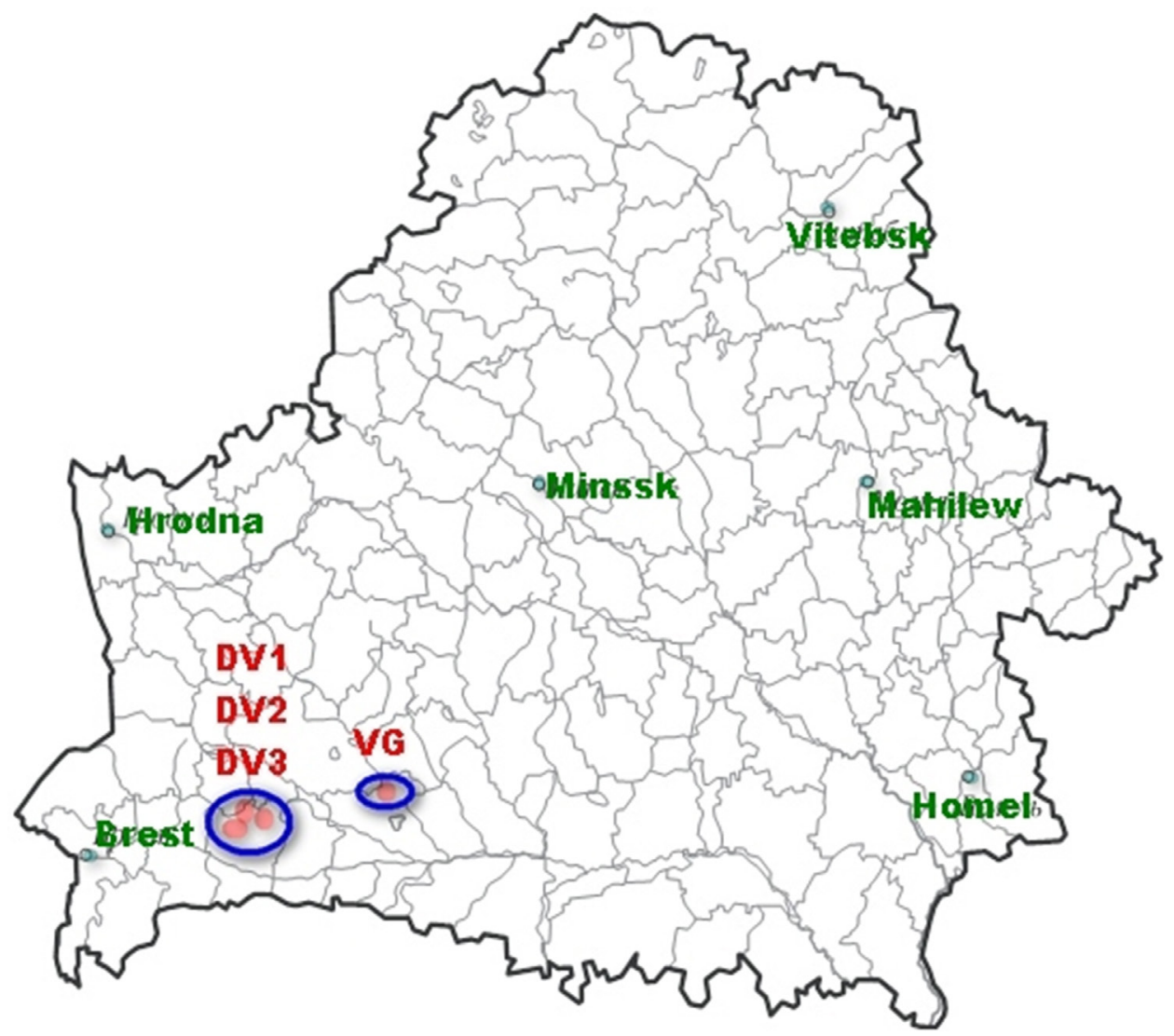

Figure 1. Distribution map of four studied coenopopulations of $C$. calceolus (DV1, DV2, DV3, VG) on the territory of the Republic of Belarus.

Total genomic DNA was isolated from dried leaf tissues by the hexadecyltrimethylammonium bromide (CTAB) method (Devi et al., 2013). The concentration and quality of the isolated DNA were examined and controlled using a NanoPhotometer nucleic acid analyzer (Pearl Implen GmbH, Germany). DNA extracts were diluted to $50 \mathrm{ng} / \mu \mathrm{l}$ for amplification by polymerase chain reaction (PCR).

For the study, 30 markers were used which were proposed by R. Kalendar et al. PCR was carried out in $25 \mu \mathrm{l}$ of a reaction mixture containing 40-50 ng of DNA, $5 \mu \mathrm{l}$ of a ScreenMix PCR ready mixture (Evrogen), $1 \mathrm{mM}$ primer for 12-13 bp. primers or $0.6 \mathrm{mM}$ for $18 \mathrm{bp}$. primers, and water. The PCR program consisted of 1 cycle at $95{ }^{\circ} \mathrm{C}$ for $5 \mathrm{~min}$; 34 cycles at $95{ }^{\circ} \mathrm{C}$ for $15 \mathrm{~s}, 50-60{ }^{\circ} \mathrm{C}$ (depending on 
primer) for $60 \mathrm{~s}$ and $68^{\circ} \mathrm{C}$ for $60 \mathrm{~s}$; final elongation $72{ }^{\circ} \mathrm{C}$ for $5 \mathrm{~min}$. Amplification was performed in a $\mathrm{C} 1000$ Touch Thermal Cycler programmable thermostat (M) Research Inc., Bio-Rad Laboratories, USA). Electrophoresis was carried out at a voltage of $65 \mathrm{~V}$ for 4.5 hours in a $2 \%$ agarose gel. The gel was stained with ethidium bromide for 30 minutes and visualized using the UV Imager Gel Doc XR + system (Bio-Rad, USA).

To create a binary data matrix using the PyElph 1.4 program, the resulting DNA amplicons were recorded as present (1) or absent (0). The binary data matrix was analyzed using POPGEN v. 1.31 to estimate the parameters of genetic diversity, including the percentage of polymorphic bands $(\mathrm{P})$, effective $(\mathrm{Ne})$ and observed number of alleles $(\mathrm{Na})$, Nei genetic diversity $(\mathrm{He})$, Shannon Information Index (I), total gene diversity $(\mathrm{Ht})$, gene flow $(\mathrm{Nm})$, gene diversity in populations $(\mathrm{Hs})$, coefficient of genetic differentiation $(\mathrm{Gst}=[\mathrm{Ht}-\mathrm{Hs}] / \mathrm{Ht})$ and gene flow between populations $(\mathrm{Nm})$. The calculation of the polymorphism information content (PIC), the average genetic distance, and analysis of molecular variance (AMOVA) were performed using the GenALEx 6.5 package. For cluster analysis of UPGMA, the SplitsTree 5 software was used.

\section{Results and discussion}

Markers 2375, 2239, 2374, 2076, 2390, and 2270 were selected to study the genetic diversity and genetic differentiation of C. calceolus, as they allowed to obtain clear DNA fragments with polymorphic loci.

For the iPBS markers used, such indicators as the number of polymorphic loci, their proportion, and the polymorphism information content (PIC) were established (Table 1).

Table 1. Characteristics of selected iPBS markers

\begin{tabular}{|l|c|c|c|c|}
\hline IPBS marker & Number of loci & $\begin{array}{c}\text { Number of } \\
\text { polymorphic } \\
\text { loci }\end{array}$ & $\begin{array}{c}\text { Proportion of } \\
\text { polymorphic } \\
\text { loci (\%) }\end{array}$ & PIC \\
\hline 2375 & 8 & 5 & 62.5 & 0.15 \\
\hline 2239 & 18 & 16 & 88.9 & 0.2 \\
\hline 2374 & 12 & 11 & 91.7 & 0.16 \\
\hline 2076 & 11 & 9 & 81.8 & 0.16 \\
\hline 2390 & 14 & 9 & 64.3 & 0.12 \\
\hline 2270 & 25 & 23 & 92.0 & 0.28 \\
\hline Total & 14.7 & 12.2 & 83.0 & 0.17 \\
\hline
\end{tabular}


Per primer, from 8 to 25 loci and from 5 to 23 polymorphic loci were obtained. The average number of loci and polymorphic loci for all primers was 14.7 and 12.2, respectively. On average, $83 \%$ of all detected loci were polymorphic. The maximum value of the measure of information polymorphism (PIC) was obtained for the marker 2270 (0.28), and the minimum for the marker 2390 (0.12). The PIC value for dominant markers ranges from 0 to 0.5 (Roldán-Ruiz et al., 2000), therefore all selected markers are informative and can be used to assess the genetic diversity of C. calceolus.

The obtained results of the analysis of genetic polymorphism in various habitats of C. calceolus, such as effective ( $\mathrm{Ne}$ ) and observed number of alleles $(\mathrm{Na})$, Shannon information index (I), and Nei genetic diversity $(\mathrm{He})$ are presented in Figure 2.

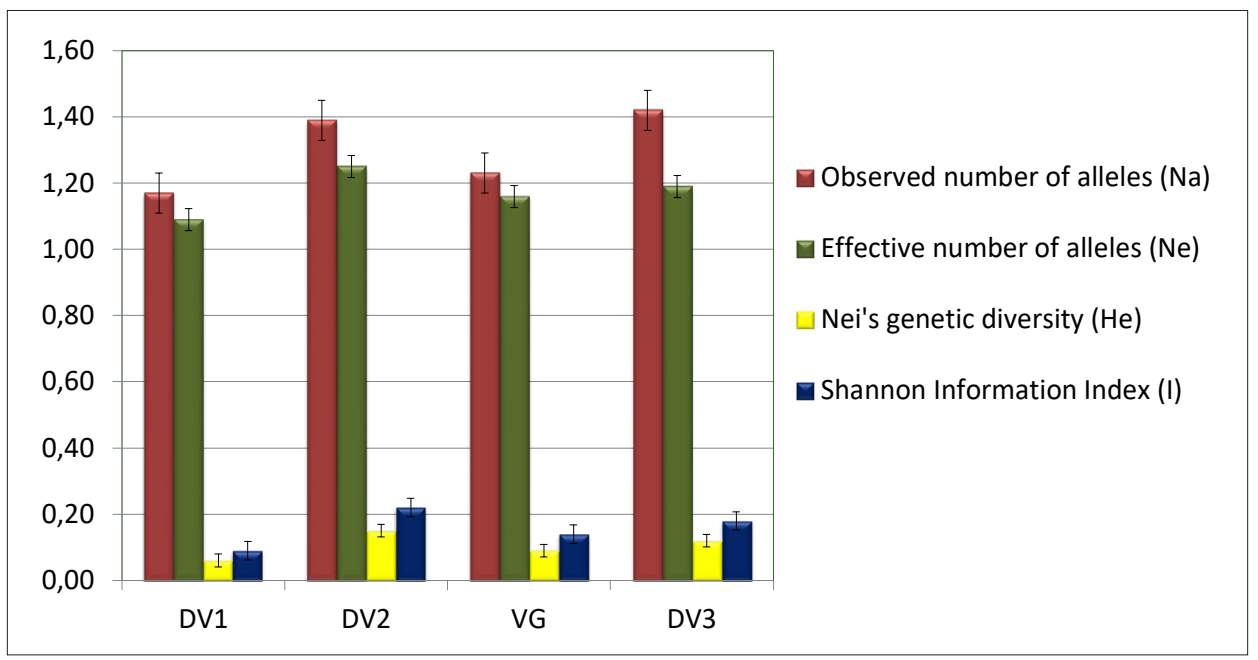

Figure 2. Parameters of genetic polymorphism of the studied coenopopulations (DV1, DV2, DV3, VG) of C. calceolus.

The results showed that in the four coenopopulation studied the observed number of alleles $(\mathrm{Na})$ ranged from 1.17 in the DV1 coenopopulation to $1.42 \mathrm{in}$ the DV3 coenopopulation. The maximum effective number of alleles (1.25) was found in the DV2 coenopopulation, and the smallest number (1.09) was found in the DV1 coenopopulation. Based on the (He) and (I) values the DV1 coenopopulation showed the lowest genetic diversity while the DV2 coenopopulation showed the highest genetic diversity.

Analysis of the interpopulation and intrapopulation genetic structure showed that the total genetic diversity $(\mathrm{Ht}=0.19 \pm 0.04)$ differs from the intrapopulation genetic diversity $(\mathrm{Hs}=0.1 \pm 0.02)$. The level of genetic differentiation among 
the studied coenopopulations of C. calceolus (Gst) was 0.45 with effective gene flow observed between coenopopulations $(\mathrm{Nm}=0.61)$. According to Nei (Nei, 1978), Gst is classified as low if Gst $<0.05$, medium when $0.05<$ Gst $<0.15$, and high when Gst $>0.15$. Thus, the Gst coefficient for C. calceolus (Gst $=0.45)$ would be considered high. The Nm value of gene flow is less than $1(\mathrm{Nm}=0.61)$, which indicates that our selected coenopopulations are subject to genetic drift since it is believed that when $\mathrm{Nm}>1$, gene flow can prevent genetic differentiation between coenopopulations caused by genetic drift (Yan et al., 2019).

Pairwise matrix and Nei genetic distance (Table 2) also show genetic differences between four coenopopulations from different regions analyzed in our study.

Table 2. Pairwise matrix of genetic similarities PhiPT (above the diagonal) and Nei genetic distance (below the diagonal)

\begin{tabular}{|l|c|c|c|c|}
\hline Coenopopulation & DV 1 & DV 2 & VG & DV 3 \\
\hline DV1 & - & 0.89 & 0.85 & 0.95 \\
\hline DV2 & 0.14 & - & 0.9 & 0.91 \\
\hline VG & 0.19 & 0.14 & - & 0.85 \\
\hline DV3 & 0.06 & 0.11 & 0.18 & - \\
\hline
\end{tabular}

This matrix showed that the largest value of Nei's genetic distance (0.19) was observed among the DV1 and VG coenopopulations, and the smallest between the DV1 and DV3 coenopopulations. This was also confirmed by the UPGMA results (Figure 3), based on Ney's distance matrix data, which demonstrate the genetic remoteness of the VG coenopopulation from the rest, which corresponds to its geographic location. The DV1 and DV3 coenopopulations are closest to each other and Nei's genetic distance between them is the smallest.

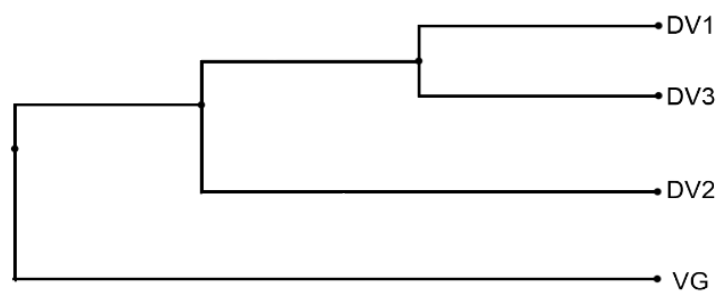

Figure 3. UPGMA dendogram (based on Ney's genetic distance) showing the relationship between the four coenopopulations studied (DV1, DV2, DV3, VG). 
Genetic differentiation between coenopopulations in AMOVA is determined using the PhiPT value (an analogue of the F-test in ANOVA), which calculates coenopopulation differentiation based on the genotypic variance of binary data (Meirmans, 2012). Phi $>0.2$ means that the coenopopulations differ significantly (Resmi et al., 2016).

AMOVA showed that most genetic diversity occurs within coenopopulations (71\%), while genetic diversity between coenopopulations is $29 \%$. The difference between individuals in the coenopopulations was statistically significant with a P-value $<0.001$. The resulting PhiPT value $=0.29$ indicates a high level of genetic differentiation among populations (Table 3). Intrapopulation genetic diversity was expected to be higher than interpopulation genetic diversity, as this distribution is a common feature of cross-pollinated species (Paschoa et al., 2018).

Table 3. AMOVA results for coenopopulations of $C$. calceolus

\begin{tabular}{|l|c|c|c|c|c|c|}
\hline \multicolumn{1}{|c|}{ Source } & df & SS & MS & Est. Var. & PhiPT & \% \\
\hline Total & 18 & 164.53 & - & 5.26 & & - \\
\cline { 1 - 5 } $\begin{array}{l}\text { Between } \\
\text { coenopopulations }\end{array}$ & 3 & 55.31 & 18.44 & 2.92 & \multirow{2}{*}{0.29 ** } & 0.29 \\
\cline { 1 - 5 } $\begin{array}{l}\text { Within } \\
\text { coenopopulations }\end{array}$ & 15 & 109.21 & 7.28 & 7.28 & & 0.71 \\
\hline
\end{tabular}

Note. ${ }^{* \star}$ - differences are significant at a significance level of $P<0.01$.

In general, the results obtained demonstrate that IPBS markers are suitable for studying the genetic diversity of $C$. calceolus, since they efficiently detected polymorphism even in individuals belonging to the same coenopopulation. The results obtained showed that the genotypes of $C$. calceolus studied in this work have a rather low level of genetic diversity. Genetic differentiation was found mainly within coenopopulations, which may be caused by the phenomenon of cross-pollination. Taking into account the obtained data on the similarities and differences between coenopopulations, it can be concluded that the coenopopulations DV1, DV2, and DV3 are a single population. Future studies should focus on more coenopopulations and samples collected from more geographic regions, and use other types of molecular markers in addition to iPBS markers to have better understand the genetic diversity of $C$. calceolus. 


\section{References}

Devi, K. D., Punyarani, K., Singh, N. S., and Devi, H. S. 2013. An efficient protocol for total DNA extraction from the members of order Zingiberales-suitable for diverse PCR based downstream applications. SpringerPlus. 2: 669.

Frankham, R. 2012. How closely does genetic diversity in finite populations conform to predictions of neutral theory? Large deficits in regions of low recombination. Heredity. 108: 167-178.

Guo, J. L., Cao, W. J., Li, Z. M., Zhang, Y. H., and Volis, S. 2019. Conservation implications of population genetic structure in a threatened orchid Cypripedium tibeticum. Plant Diversity. 41: $13-18$.

John, A. L. de W., Mäder, G., Fregonezi, J. N., and Freitas, L. B. 2019. Genetic diversity and population structure of naturally rare Calibrachoa species with small distribution in southern Brazil. Genetics and Molecular Biology. 42: 108-119.

Kachanovsky, I. M. (ed.). 2015. The Red Book of the Republic of Belarus: Plants: The rare and endangered species of wild plants. Belarusian Encyclopedia named after P. Brovki. Minsk, 445 p.

Kalendar, R., Antonius, K., Smýkal, P., and Schulman, A. H. 2010. iPBS: a universal method for DNA fingerprinting and retrotransposon isolation. TAG. Theoretical and Applied Genetics. Theoretische Und Angewandte Genetik. 121: 1419-1430.

Meirmans, P. G. 2012. AMOVA-based clustering of population genetic data. The Journal of Heredity. 103: 744-750.

Mikhalchuk, N. V. 1997. Scientific Substantiation of the organization of the biological reserve "Divin - Velikiy Les". Brest, 17 p.

Minasiewicz, J., Znaniecka, J. M., Górniak, M., and Kawiński, A. 2018. Spatial genetic structure of an endangered orchid Cypripedium calceolus (Orchidaceae) at a regional scale: limited gene flow in a fragmented landscape. Conservation Genetics. 19: 1449-1460.

Nei, M. 1978. Estimation of average heterozygosity and genetic distance from a small number of individuals. Genetics. 89: 583-590.

Paschoa, R. P., Christ, J. A., Valente, C. S., Ferreira, M. F. da S., Miranda, F. D. de, Garbin, M. L., Carrijo, T. T., Paschoa, R. P. da, Christ, J. A., Valente, C. S., Ferreira, M. F. da S., Miranda, F. D. de, Garbin, M. L., and Carrijo T. T. 2018. Genetic diversity of populations of the dioecious Myrsine coriacea (Primulaceae) in the Atlantic Forest. Acta Botanica Brasilica. 32: 376-385.

Resmi, L., Nair, A. R., and Nair, A. S. 2016. Population genetic structure and diversity analysis of South Indian banana cultivars. Journal of Plant Breeding and Crop Science. 8: 1-12.

Roldán-Ruiz, I., Dendauw, J., Van Bockstaele, E., Depicker, A., and De Loose, M. 2000. AFLP markers reveal high polymorphic rates in ryegrasses (Lolium spp.). Molecular Breeding. 6: 125-134.

Yan, W., Li, J., Zheng, D., Friedman, C., and Wang, H. 2019. Analysis of genetic population structure and diversity in Mallotus oblongifolius using ISSR and SRAP markers. Peer J. 7: e7173. 